\title{
Foresight for Small and Medium Enterprises in the Context of the Circular Economy
}

\author{
Wendy Anzules-Falcones \\ Researcher and Professor of Business Administration, wendy.anzules@udla.edu.ec \\ Angela María Díaz-Márquez \\ Researcher and Professor of Urban Studies, angela.diaz@udla.edu.ec

\section{León Padilla} \\ Researcher and Professor of Economy and Business, leon.padilla@udla.edu.ec
}

\section{Daniel Hernán-Hidalgo}

Msc. Professor of Environmental Engineering (waste specialist), daniel.hidalgo@udla.edu.ec

\section{David Sánchez-Grisales}

PhD candidate. Msc. Professor of Product Design (specialist in ecodesign), david.sanchez.grisales@udla.edu.ec

\begin{abstract}
$\mathrm{S}$ mall, medium, and micro enterprises make important contributions to economic growth and employment. Based on evidence from of the tire processing industry in Ecuador, this article assesses the development prospects for such companies in the context of the transition to a circular economy. The methodological basis of this study is scenario planning. Five scenario hypotheses are proposed and the probability of their implementation
\end{abstract}

Abstract

\section{Keywords:}

strategic foresight; scenario planning; management;

MSMEs; circular economy is estimated. The most optimal scenario (in which all five hypotheses are realized) is feasible and subject to a set of measures, including the development of new management and marketing tools, the involvement of universities and research centers in the creation of new low-cost waste processing technologies, and the organization of a special fund to support research and development in companies focused on the circular model.
Citation: Anzules-Falcones W., Díaz-Márquez A.M., Padilla L., Hernán-Hidalgo D., Sánchez-Grisales D. (2021) Foresight for Small and Medium Enterprises in the Context of the Circular Economy. Foresight and STI Governance, 15(1), 86-96. DOI: 10.17323/25002597.2021.1.86.96 
$\mathrm{T}$ he economic contribution of micro, small, and medium enterprises (MSMEs) can hardly be overestimated. In OECD countries, MSMEs constitute $99 \%$ of all enterprises. In terms of employment generated, it is estimated that nearly $65 \%$ workers are employed at SMEs and nearly 30\% of people work in a micro-enterprise [OECD, 2019]. The business dynamism, the development of technology, the reduction of barriers, and telecommunications have helped SMEs access the global market [Dabić et al., 2020]. Nevertheless, most SMEs do not have any formalized strategies and a narrow assessment of the competitive environment. Latin America's MSMEs, in addition to exogenous challenges ${ }^{1}$, particularly face such obstacles as an internal firm structure based on family ties that makes MSMEs vulnerable in terms of management, leadership style, and competition.

Despite this, there are some positive aspects to emphasize, such as the flexibility and adaptation to new production matrices in times of crises that regularly occur due to high volatility, uncertainty, ambiguity, and business complexity [Doheny et al., 2012; Bennett, Lemoine, 2014]. Making the firm's dynamic capabilities work implies a continuous training process as well as restructuring strategies and business models.

Without a doubt, MSMEs in Latin America consider implementing the emerging circular economy paradigm a space for great opportunities that particularly allow for improving environmental quality. In this region, each inhabitant generates almost one kilogram of garbage per day (231 million tons of waste annually) and only $4.5 \%$ of waste is recycled in the entire region [Kaza et al., 2018]. To approximately four million people in Latin America, their main source of income is generated by recovery, separation, and informal commercialization of garbage [Stephenson, Faucher, 2019]. The Ministry of Environment (El Ministerio del Ambiente, MAE) of Ecuador has made important efforts to regulate the recovery, disposal, and management of waste tires in the country with a key role played by specialized MSMEs in this field. However, in order for these companies to be able to solve the assigned tasks, they must improve their competencies. In turn, the government will have to improve the mechanisms of external regulation of their activities [Laure et al., 2017].

The current worldwide recycling technologies for waste pneumatic tires allow for various products (see Table 1). However, the demand for certain types of products is not balanced due to the fact that the obtained "raw material" rarely meets the required characteristics, which means alternative solutions must be found [Dobrotă et al., 2020]. The most efficient alternative is devulcanization that allows for significantly expanding the range of the new rubber materials and, accordingly, the range of products in demand [Dobrotă, Dobrotă, 2018].

This study analyzes the possible futures of MSMEs in the waste pneumatic tire sector employing the strategic foresight methodology. It results in the proposal of improvements in the growth of the activities of these enterprises and generating information that can improve national public policy regarding the circular economy. The methodology used and results obtained are important for studying the performance of these companies in other production cycles linked to the circular economy paradigm.

\section{Literature Review}

Large companies are led by executives with professional experience and management skills to manage them efficiently and effectively. While the fundamental nature of MSMEs (family-owned, small-sized, and focused on survival) makes it impossible to establish a rigid management scheme like those of large companies [Block, 2012; Migliori et al., 2020]. In MSMEs, the founder generally assumes the functions that can decide upon the future of the organization [Herrmann, Nadkarni, 2014; Vandekerkhof et al., 2018; Diéguez-Soto et al., 2018]. Traditionally family firms have been adverse to hiring external managers to the top management team in an attempt to retain family control [Breton-Miller et al., 2011; Vandekerkhof et al., 2015]. On the other hand, studies show that, provided that when nurturing a specific corporate culture, the hiring of non-family personnel enables an increase in the dynamic capabilities of a firm [Teece et al., 2009; Dekker et al., 2015; Howorth et al., 2016; Wilden et al., 2016]. Such a culture involves coordination and collaboration programs, information sharing across functions and firms' departments, as well as the rapid codification and integration of knowledge gained as a result of dynamic interactions of employees both with internal and external partners [Cohen, Bailey, 1997; Zahra et al., 2004; Gunday et al., 2011; Un, Asakawa, 2015; Cassia et al., 2012; Chirico, Nordqvist, 2010; Volberda et al., 2010].

In Ecuador, MSMEs have a share of $99.53 \%$ of all enterprises, while microenterprises correspond to $90.81 \%$ (Table 2). MSMEs in Ecuador operate in the following sectors: food, construction, graphics, wood, metallurgy, electrical, textiles, chemicals, and ICT [Burneo, 2016]. As of 2018, there were 899,208 enterprises, of which 816,553 were microbusinesses and 64,117 were small businesses. ${ }^{2}$

Regarding sectors linked to the circular economy paradigm (companies that work with waste as inputs for new products), efforts to encourage the creation of a productive cycle are very recent, but the creation of

\footnotetext{
According to a World Bank report, MSMEs generally face external problems such as corruption, taxation, excessive regulations, lack of credit and an unstable political environment [World Bank, 2017].

According to the Instituto Nacional de Estadística y Censos (INEC).
} 


\section{Table 1. Used Tire Utilization Matrix}

\begin{tabular}{|l|l|}
\hline \multicolumn{1}{|c|}{$\begin{array}{c}\text { Types of use and/or } \\
\text { enhancement }\end{array}$} & \multicolumn{1}{c|}{ By-products obtained } \\
\hline Retreading & Retreated tires \\
\hline $\begin{array}{l}\text { Shredding (intermediate stage of } \\
\text { use) }\end{array}$ & $\begin{array}{l}\text { Rubber powder, rubber } \\
\text { pellets, rubber chips }\end{array}$ \\
\hline Recycling for artisanal purposes & Household goods, car details \\
\hline High-tech recycling & Road coatings \\
\hline Pyrolysis & Fuel \\
\hline Co-processing & $\begin{array}{l}\text { Construction materials, } \\
\text { electric power }\end{array}$ \\
\hline $\begin{array}{l}\text { Source: Ministry of Environment, 2019. https://www.ambiente.gob.ec/, } \\
\text { accessed 02.02.2021 }\end{array}$ \\
\hline
\end{tabular}

the Plan for the Integrated Management of Used Tires $(\mathrm{PIMUT})^{3}$ represents a significant advance and a precedent for managing other waste. Ecuador discards millions of tires annually, a portion of which is reused for retreading, but most are either incinerated or deposited in open-air dumps, threating the environment. In Quito, there are 25 companies involved in the environmental management of used tires ${ }^{4}, 20$ of which have environmental permits issued by the MAE, but only four are large companies (following the classification criteria presented in Table 3). Only seven environmental management companies use more than $80 \%$ of their existing capacity, of which four are MSMEs.

The Ministry of the Environment (MAE) has established progressive and incremental targets for the recovery of waste tires for importers and/or producers of tires in Ecuador. ${ }^{5}$ The PIMUT detailed the process to be followed by importers and producers in relation to the marketing chain, communication mechanisms, collection, return, accumulation, transport, treatment, final disposal, and export. Through the PIMUT, a productive cycle linked to the circular economy paradigm has been activated. The large companies must recover the waste with the support of environmental managers, in the shape of MSMEs. According to the management capacity of MSMEs, the generation of a fair market for the effective use of this type of waste and the promotion of the inclusion of MSMEs within new production cycles was expected. However, among the initial challenges were limited demand and a high cost of new technologies versus the costs of the management of the tires received, which does not promise significant gains in the short term. Aid from the government represented by the MAE leads to certain, positive shifts, but they are not sufficient from a business point of view.

In the entire country, there are only three companies (MSMEs) possessing the often expensivecapacities to shred used tires: Rubber Action, Ecollantas, and Incinerox. Rubber Action was faced with decreased
Table 2. Structure of Ecuadorean Companies According to Their Size

\begin{tabular}{|l|l|}
\hline Size of business & No. of businesses \\
\hline Micro business & 816553 \\
\hline Small business & 64117 \\
\hline Medium A business & 8529 \\
\hline Medium B business & 5749 \\
\hline Large business & 4260 \\
\hline Total & 899208 \\
\hline Source: compiled by the authors using [INEC, 2019]. \\
\hline
\end{tabular}

demand in 2019 due to the saturation of the market with used tires (unshredded residue). The company asked the national government to encourage the use of the tire powder. However, aid from the government was insufficient, which is why Rubber Action sought allies at several universities in Ecuador, especially in the city of Quito in attempt to design a less costly processing technology.

\section{Study Method}

The aim of this study is to generate future scenarios on the operations of MSMEs dedicated to the management of waste pneumatic tires in Ecuador. These scenarios have been generated through a strategic foresight methodology. The research is divided into three stages:

- Literature review, reviewing the theories related to management at MSMSs, identifying the main components of the strategic foresight methodology and, thus, choosing the most appropriate tools according to the research objective.

- Interviews and working sessions with stakeholders about variables and hypotheses, based on the defined strategic foresight methodology.

- Data collection from experts and data processing using the tools defined at stage one to obtain the future scenarios matrix.

The research and practice of strategic foresight has a tradition that reaches back to the late 1940s [Coates et al., 2010]. Foresight grew out of the pioneering work of

Table 3. Classification Variables: Company Size

\begin{tabular}{|l|l|l|}
\hline \multicolumn{1}{|c|}{ Size } & \multicolumn{1}{|c|}{$\begin{array}{c}\text { Annual sales } \\
\text { (USD millions) }\end{array}$} & $\begin{array}{l}\text { Number of affiliated } \\
\text { staff members }\end{array}$ \\
\hline Large & More than 5 & 200 \\
\hline Medium B & $2-5$ & $100-199$ \\
\hline Medium A & $1-2$ & $50-99$ \\
\hline Small & $0.1-1$ & $10-49$ \\
\hline Micro & Less than 0.1 & $1-9$ \\
\hline \multicolumn{2}{|l|}{ Source: compiled by the authors using [INEC, 2019]. }
\end{tabular}

\footnotetext{
Approved by the Ministerial Agreement No. 20 of 2015. Finished at 2020.

Currently, the organizations dedicated to the management of waste pneumatic tires are within the Standard International Industrial Classification E3830.02 related to the recovery of rubber products such as used tires to obtain raw materials [INEC, 2020].

Through the National Program for the Integrated Management of Solid Waste (Spanish acronym: PNGIDS) under Ministerial Agreement 98 in 2013.
} 
Bertrand de Jouvenel and Gaston Berger [de Jouvenel, 1967; Berger, 1964] who emphasized the need to create shared future perspectives in a management group. In the run of the following decades, numerous research studies used mathematics, probability, and operational research to establish some techniques in relation to the scenario method, structural analysis, cross-impact matrices, and the strategies established by actors. These tools have allowed foresight to be used at any type of company [Medina Vásquez, 2006].

Scenario planning is a key ally of organizations in terms of strategic planning. It allows for comparing various alternative evolution paths and choosing the preferred one [Schwartz, 1996]. Two types of scenarios stand out: exploratory scenarios, which start from the past and present trends that allow for futures; and anticipatory scenarios, which originate with the outlines of a desired future [Godet, Durance, 2011]. In business areas such as finance or human resources and also in studies related to the environment, the scenario planning technique is applied to understand future contingencies about a local or national problem. In the field of technology, scenario planning is also valid, for example in Indonesia, Hutajulu et al. established two scenarios for $5 \mathrm{G}$ implementation, a model that was designed by analyzing the respondents' ideas [Hutajulu et al., 2020]. As with other tools of strategic foresight, scenario planning allows decision makers to establish a course of action, predict the effects, and incorporate strategic resources in order to achieve a significant competitive position [Rohrbeck, 2012; Peter, Jarratt, 2015; Gavetti, Menon, 2016].

Scenario planning is used in our study to evaluate the possible future scenarios of MSMEs dedicated to the management of waste pneumatic tires in an increasingly complex business environment. The authors chose this sector because in Ecuador since 2020, a roadmap toward the circular economy has been established in which the public and private sectors participate, emphasizing the MSMEs dedicated to the management of waste pneumatic tires. The initial step was the signing of a National Pact for a Circular Economy in which more than 160 organizations committed to support the lines of action to implement this concept and is a sign that shows the future based on four pillars: sustainable production, responsible consumption, integrated waste management, and policy and financing mechanisms for circular projects. ${ }^{6}$ With this background, we consider it is important to carry out this exploratory research using strategic foresight to establish future scenarios that will allow MSMEs to define strategies to face the rapidly changing and complex environment. The strategic foresight method is structured around several stages, as shown in Figure 1.

Figure 1. Stages of Strategic Foresight

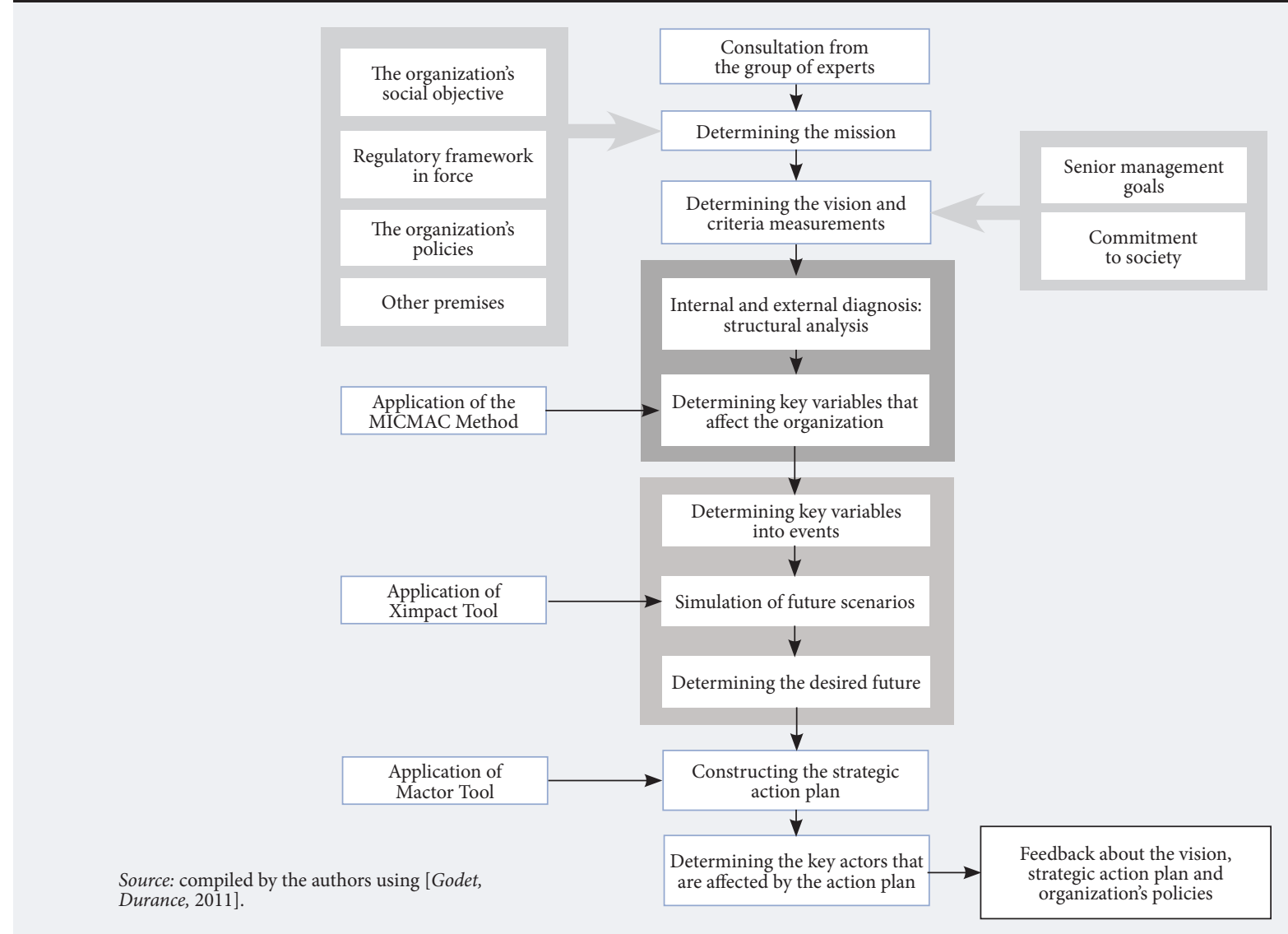

\footnotetext{
${ }^{6}$ https://www.produccion.gob.ec/ecuador-camina-firme-en-la-ruta-de-la-economia-circular/, accessed 13.02.2021.
} 


\section{Interviews with Experts}

The questionnaires were compiled during preliminary working sessions with experts to link the questions to the objective of the study: the situation of MSMEs dedicated to the management of tire waste. The list of experts was determined, chosen based on their knowledge and experience in the sector, using the "Propone" method and software, which facilitates calculations by establishing a weight based on the criteria considered for each expert [García Peñalvo, 2010]. The experts' background is provided at the Table 4 .

Five hypotheses were defined as a result of interviews in relation to (1) production optimization, (2) quality inputs, (3) efficient management of financial resources, (4) obtaining by-products, and (5) the research and development processes.

\section{Analytical Tools}

After a bibliographic review of the method and its components, we decided to use the following tools, which corresponded to the study's objective.

MICMAC analysis. The acronym MICMAC comes from the words "cross-impact matrix multiplication applied to classification" [Godet et al., 2007]. The MICMAC structural method seeks to analyze, in a qualitative way, the relationships between the variables that make up a system within a company, organization, society, country, and so on. The objective of the MICMAC Structural Analysis is to identify the main variables, influential and dependent, as well as the essential variables for the evolution of the system. Using MICMAC software, a list of 11 variables of the MSMEs' sector of waste pneumatic tire management was made and relationships between the variables were determined and the key variables established.

MACTOR analysis. The MACTOR method (Matrix of Alliances and Conflicts: Tactics, Objectives and Recommendations) proposes a way for analyzing the role played by the stakeholders in the study dynamics [Godet et al., 2007].

\section{Table 4. The Experts Background}

\begin{tabular}{|l|l|}
\hline Expert & \multicolumn{1}{c|}{ Position, background } \\
\hline 1 & $\begin{array}{l}\text { Ministry of Environment- Specialist of the National } \\
\text { Program for the Integral Management of Solid Waste } \\
\text { (PNGIDS). }\end{array}$ \\
\hline 2 & $\begin{array}{l}\text { Secretary of Environment of the Municipality of } \\
\text { Quito - Director of Environmental Policies and } \\
\text { Planning. }\end{array}$ \\
\hline 3 & $\begin{array}{l}\text { Manager of Proyección Futura-Gestión y Reciclaje } \\
\text { Integral de Neumáticos. Environmental Manager } \\
\text { who develops and implements management systems } \\
\text { for integrated waste management. }\end{array}$ \\
\hline 4 & $\begin{array}{l}\text { Manager of Ecocaucho-Industria Recicladora } \\
\text { de Caucho S.A.: company dedicated to the } \\
\text { manufacture of recycled rubber products through } \\
\text { the management of end-of-life tires. }\end{array}$ \\
\hline Source: compiled by the authors. \\
\hline
\end{tabular}

Table 5. Identified Variables

\begin{tabular}{|l|l|l|}
\hline No. & \multicolumn{1}{|c|}{ Long label } & \multicolumn{1}{|c|}{ Short label } \\
\hline 1 & Management of input purchases & inputpurch \\
\hline 2 & Storage capacity & StorCap \\
\hline 3 & Transport capacity & TranspCap \\
\hline 4 & Production capacity & ProdCap \\
\hline 5 & Quality processes & QualProc \\
\hline 6 & Operating costs & OperCosts \\
\hline 7 & Financial resources available & FinanRec \\
\hline 8 & Workforce productivity & WorkFProd \\
\hline 9 & Strategic planning & StratPlan \\
\hline 10 & Research and development/innovation & R\&D \\
\hline 11 & Commercial strategies (market and sales) & Mkt\&Sales \\
\hline Source: compiled by the authors. & \\
\hline
\end{tabular}

SCIM analysis. The SCIM (Systems and Cross Impact Matrices), developed at the Battelle Institute in Geneva, is designed is to determine the probability of the scenarios created according to the hypotheses defined. For each expert, the probability of each scenario is calculated using a quadratic minimization method. The results are obtained for each expert and over the set of experts, establishing the weighted average of the probabilities calculated for each expert [Quinteros, Hamann, 2017]. Once the probability solutions of the scenarios are calculated, a choice criterion is introduced: it is established as the ideal solution that corresponds to the set (probabilities of the scenarios). The most probable scenario is the one with the highest possible value (on the average that the experts considered when answering the questionnaire). The solution that meets this criterion is obtained by the simplex algorithm, since it is a linear function to be optimized under linear problems ${ }^{7}$. When a system of $N$ hypotheses is considered (sets of hypotheses or scenarios), it is possible to choose which of the $N$ possible hypotheses should be taken into account due to the probability of realization, which is estimated on the scale from a probability of 1 (very weak) to a probability of 5 (very probable). Then the probabilities of the scenarios are established, in which the analysis of the experts' responses is carried out thus providing a probability for each of the $N$ possible combinations of the $N$ hypotheses [Astigarraga, 2016].

\section{Results}

The tools of the prospective method were applied to the operations of the MSMEs dedicated to the management of waste pneumatic tires to determine future scenarios and identify strategies that allow for better performance and competitiveness.

The MICMAC Analysis covered the 11 variables (Table 5). These variables were crossed in the direct impact matrix (Table 6), in which each cell represented the relationship of two variables:

http://es.laprospective.fr/Metodos-de-prospectiva/Los-programas/70-Smic-Prob-Expert.html, accessed 15.02.2021. 


\section{Table 6. Matrix of Direct Impacts}

\begin{tabular}{|c|c|c|c|c|c|c|c|c|c|c|c|}
\hline & 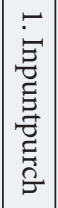 & 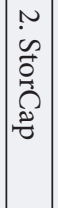 & 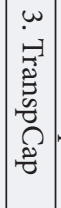 & 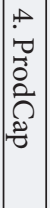 & 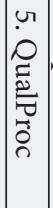 & 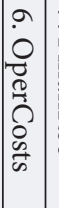 & 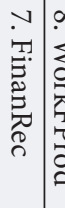 & 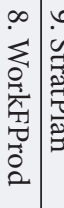 & 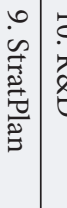 & 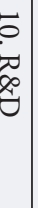 & 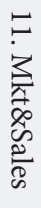 \\
\hline 1. Inpuntpurch & 0 & 1 & 1 & 1 & 1 & 1 & 1 & 0 & 0 & & 0 \\
\hline 2. StorCap & 0 & 0 & 0 & 0 & 1 & 1 & 1 & 0 & 1 & 0 & 0 \\
\hline 3. TranspCap & 0 & 0 & 0 & 0 & 0 & \begin{tabular}{|l|l}
1 \\
\end{tabular} & 1 & 1 & 1 & & 0 \\
\hline 4. ProdCap & 1 & 1 & 1 & 0 & 1 & \begin{tabular}{|l|}
1 \\
\end{tabular} & 1 & 1 & 1 & 1 & 1 \\
\hline 5. QualProc & 1 & 1 & 1 & 0 & 0 & 1 & 1 & 1 & 1 & & 1 \\
\hline 6. OperCosts & 0 & 0 & 0 & 0 & 1 & \begin{tabular}{|l|l}
0 & $(1$ \\
\end{tabular} & 0 & 1 & 1 & 1 & 1 \\
\hline 7. FinanRec & 0 & 0 & 0 & 1 & 1 & 11 & 0 & 0 & 1 & & 1 \\
\hline 8. WorkFProd & 0 & 0 & 0 & 1 & 1 & 1 & 0 & 0 & 1 & & 1 \\
\hline 9. StratPlan & 0 & 0 & 0 & 1 & 1 & 1 & 0 & 0 & 1 & 1 & 1 \\
\hline 10. $\mathrm{R} \& \mathrm{D}$ & 1 & 1 & 1 & 1 & 1 & \begin{tabular}{|l|}
1 \\
\end{tabular} & 1 & 1 & 0 & 0 & 1 \\
\hline 11. Mkt\&Sales & 0 & \begin{tabular}{|l|l|}
0 & \\
\end{tabular} & 0 & 1 & 1 & \begin{tabular}{|l|l}
1 \\
\end{tabular} & 1 & 0 & 1 & 1 & 0 \\
\hline
\end{tabular}

\section{0: No influence}

1: Weak influence

2: Average influence

3: Strong influence

Q: Potential influence

By raising this matrix to the successive powers $(1,2,3 \ldots)$ until it was stable (so that the order of the factors is not altered), the indirect impact matrix shown in Table 7 was achieved. In this matrix, the sum of each column generated the dependency value and the sum of the values of each row, that is, the total dependency value. This procedure was applied for each variable.

As a result of this process, five key unstable variables were identified in case of MSMEs. These are: Production Capacity, Research \& Development, Quality Processes, Management of Input Purchases, and Financial Resources. These key variables are those considered in this study for the development of the next stages of scenario design.

\section{MACTOR Analysis allowed the authors to identify} the stakeholders who influence and control the key variables in one way or another. At the same time, the main objectives linked to the key variables pursued by the stakeholders were identified (Table 8).

SCIM Analysis resulted in the formulation of the scenario hypotheses for each variable; the results are shown in Table 9.

Experts were consulted about the probability of fulfilling the proposed hypotheses. Forms were structured for simple, conditional positive, and negative probabilities. By means of an interview, the experts analyzed and filled out the forms that were then processed using SMIC software, thus obtaining the future scenarios.

\section{Table 7. Matrix of Indirect Impacts}

\begin{tabular}{|c|c|c|c|c|c|c|c|c|c|c|c|}
\hline & 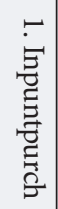 & 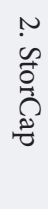 & 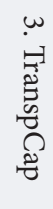 & 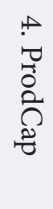 & 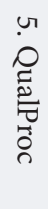 & $\begin{array}{l}0 \\
0 \\
0 \\
0 \\
0 \\
0 \\
0 \\
0 \\
\omega\end{array}$ & 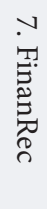 & 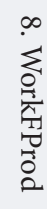 & $\mid \begin{array}{l}0 \\
0 \\
\tilde{E} \\
\tilde{0} \\
\tilde{0} \\
\tilde{\Xi}\end{array}$ & $\begin{array}{l}\sigma \\
\dot{0} \\
\check{C} \\
\theta\end{array}$ & 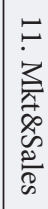 \\
\hline 1. Inpuntpurch & 11 & 14 & 14 & 29 & 40 & 42 & 25 & 20 & 38 & 38 & 34 \\
\hline 2. StorCap & 9 & 10 & 10 & 15 & 21 & 22 & 16 & 13 & 21 & 19 & 18 \\
\hline 3. TranspCap & 11 & 11 & 11 & 12 & 18 & 19 & 15 & 14 & 19 & 18 & 18 \\
\hline 4. ProdCap & 21 & 23 & 23 & 33 & 51 & 53 & 35 & 33 & 52 & 49 & 48 \\
\hline 5. QualProc & 20 & 21 & 21 & 27 & 43 & 45 & 30 & 30 & 45 & 43 & 43 \\
\hline 6. OperCosts & 12 & 14 & 14 & 19 & 30 & 31 & 22 & 19 & 30 & 28 & 26 \\
\hline 7. FinanRec & 13 & 16 & 16 & 26 & 37 & 40 & 27 & 21 & 37 & 34 & 31 \\
\hline 8. WorkFProd & 13 & 16 & 16 & 26 & 37 & 40 & 27 & 21 & 37 & 34 & 31 \\
\hline 9. StratPlan & 10 & 13 & 13 & 24 & 33 & 36 & 23 & 17 & 32 & 30 & 27 \\
\hline 10. R\&D & 21 & 23 & 23 & 34 & 51 & 53 & 35 & 33 & 52 & 48 & 48 \\
\hline 11. Mkt\&Sales & 13 & 16 & 16 & 26 & 37 & 40 & 28 & 21 & 37 & 34 & 30 \\
\hline
\end{tabular}

\section{Scenario Probabilities}

After the probabilistic analysis, we constructed the various combinations of either performance, or the lack thereof, within the hypotheses, which generated multiple future scenarios with varying probabilities of realization (Table 10). The code representing the scenario is composed of a two-digit number representing the hypothesis followed by five spaces for single-digit numbers (only 0 and 1 ) representing the five key hypotheses. The figure " 0 " indicates that the hypothesis has not been fulfilled, whereas " 1 " indicates that it has been met. For example, if scenario 17 is presented as $17-01111$, then scenario 17 is interpreted as having fulfilled hypotheses $2,3,4$, and 5 , whereas hypotheses 1 has not been fulfilled (as it has a value of 0 ). Table 10 shows the probability of carrying out the possible sce-

\section{Table 8. List of Identified Actors and Objectives}

\begin{tabular}{|l|l|}
\hline Stakeholders & $\begin{array}{l}\text { Chamber of Small and Medium Industry } \\
\text { (CAPEIPI) }\end{array}$ \\
\cline { 2 - 2 } & Ministry of Environment \\
\cline { 2 - 2 } & $\begin{array}{l}\text { Environment Secretary Office for the } \\
\text { Municipality of Quito }\end{array}$ \\
\cline { 2 - 2 } Objectives & $\begin{array}{l}\text { Optimize the operation/production phase that } \\
\text { generates value }\end{array}$ \\
\cline { 2 - 2 } & $\begin{array}{l}\text { Establish processes to achieve research and } \\
\text { development }\end{array}$ \\
\cline { 2 - 2 } & Develop quality by-products \\
\cline { 2 - 2 } & $\begin{array}{l}\text { Acquire inputs from suppliers that provide } \\
\text { quality and conform to environmental policies }\end{array}$ \\
\hline & $\begin{array}{l}\text { Establish a system for the optimization of } \\
\text { financial resources }\end{array}$ \\
\hline Source: compiled by the authors.
\end{tabular}


Table 9. List of Variables and Assumptions about the Probabilities that Future Hypotheses Come True

\begin{tabular}{|c|c|}
\hline Variable & $\begin{array}{c}\text { Future Hypothesis }(\text { Time horizon }=5 \\
\text { years) }\end{array}$ \\
\hline $\begin{array}{l}\text { Production } \\
\text { capacity }\end{array}$ & $\begin{array}{l}\text { The MSMEs in the sector will have a } \\
\text { production process that generates value } \\
\text { and an environmental policy }\end{array}$ \\
\hline $\begin{array}{l}\text { Research \& } \\
\text { development }\end{array}$ & $\begin{array}{l}\text { The MSMEs in the sector will have a } \\
\text { process that encourages research and } \\
\text { development }\end{array}$ \\
\hline Quality processes & $\begin{array}{l}\text { The MSMEs will be producing quality } \\
\text { by-products while protecting the } \\
\text { environment }\end{array}$ \\
\hline $\begin{array}{l}\text { Management of } \\
\text { input purchases }\end{array}$ & $\begin{array}{l}\text { The sector's MSMEs will have an efficient } \\
\text { input purchasing process and suppliers } \\
\text { that provide quality and comply with an } \\
\text { environmental policy }\end{array}$ \\
\hline $\begin{array}{l}\text { Financial } \\
\text { resources }\end{array}$ & $\begin{array}{l}\text { There will be a system for the optimization } \\
\text { of financial resources }\end{array}$ \\
\hline
\end{tabular}

narios that respond to the combination of their occurrence or non-occurrence. Note from the accumulated percentage column that the trend core is given by 10 scenarios that represent more than $70 \%$ of the realization of all the hypotheses. Two of them have a greater presence - scenario 32 and scenario 1 - which individually have a probability of occurrence of $16.30 \%$ and $15.30 \%$, respectively.

\section{The Selection of the Best Scenario}

If the most likely scenario would have only 0 values, it could be called a "total extermination" [Mitma et al., 2009], which is scenario 32 in our case study as it has 00000 and is the one with the highest probability of occurrence $(16.30 \%)$. This can also be called the trend scenario. On the other hand, the scenario we call the "Garden of Eden" in our research is scenario 01 11111, which also has a high probability of occurrence (15.30\%), but this one will require strategic actions.

Table 10. Probability Matrix for Each Scenario

\begin{tabular}{|c|c|c|c|c|c|c|c|c|}
\hline Scenario & H1 & $\mathrm{H} 2$ & H3 & H4 & H5 & Group of experts (indiv prob) & Prob (\%) & Accum (\%) \\
\hline $32-00000$ & 0.146 & 0.097 & 0.19 & 0.183 & 0.2 & 0.163 & 16.30 & 16.30 \\
\hline $01-11111$ & 0.137 & 0.294 & 0.182 & 0.038 & 0.115 & 0.153 & 15.30 & 31.60 \\
\hline $17-01111$ & 0.081 & 0.099 & 0.164 & 0.021 & 0.081 & 0.089 & 8.90 & 40.50 \\
\hline $05-11011$ & 0.111 & 0.078 & 0.04 & 0.047 & 0.064 & 0.068 & 6.80 & 47.30 \\
\hline $02-11110$ & 0.05 & 0.093 & 0 & 0.038 & 0.097 & 0.056 & 5.60 & 52.90 \\
\hline $09-10111$ & 0.062 & 0.143 & 0.024 & 0.031 & 0 & 0.052 & 5.20 & 58.10 \\
\hline $03-11101$ & 0.058 & 0.006 & 0.011 & 0.047 & 0.058 & 0.036 & 3.60 & 61.70 \\
\hline $04-11100$ & 0.008 & 0 & 0.073 & 0.031 & 0.041 & 0.03 & 3.00 & 64.70 \\
\hline $06-11010$ & 0.045 & 0.012 & 0.024 & 0.031 & 0.033 & 0.029 & 2.90 & 67.60 \\
\hline $21-01011$ & 0.04 & 0 & 0.032 & 0.029 & 0.035 & 0.027 & 2.70 & 70.30 \\
\hline $07-11001$ & 0.048 & 0 & 0 & 0.04 & 0.036 & 0.025 & 2.50 & 72.80 \\
\hline $19-01101$ & 0.012 & 0.005 & 0.058 & 0.029 & 0.021 & 0.025 & 2.50 & 75.30 \\
\hline $25-00111$ & 0.027 & 0 & 0.064 & 0.011 & 0.016 & 0.024 & 2.40 & 77.70 \\
\hline $16-10000$ & 0.016 & 0.034 & 0.018 & 0.003 & 0.038 & 0.022 & 2.20 & 79.90 \\
\hline $14-10010$ & 0.004 & 0.023 & 0.017 & 0.021 & 0.042 & 0.021 & 2.10 & 82.00 \\
\hline $13-10011$ & 0.029 & 0.028 & 0 & 0.039 & 0 & 0.019 & 1.90 & 83.90 \\
\hline $10-10110$ & 0.017 & 0.003 & 0 & 0.029 & 0.034 & 0.016 & 1.60 & 85.50 \\
\hline $11-10101$ & 0.025 & 0.015 & 0 & 0.039 & 0 & 0.016 & 1.60 & 87.10 \\
\hline $29-00011$ & 0 & 0 & 0.021 & 0.018 & 0.042 & 0.016 & 1.60 & 88.70 \\
\hline $12-10100$ & 0.015 & 0 & 0.03 & 0.022 & 0.003 & 0.014 & 1.40 & 90.10 \\
\hline $18-01110$ & 0.021 & 0.002 & 0 & 0.038 & 0 & 0.012 & 1.20 & 91.30 \\
\hline $24-01000$ & 0 & 0.049 & 0 & 0.006 & 0 & 0.011 & 1.10 & 92.40 \\
\hline $15-10001$ & 0.007 & 0.013 & 0 & 0.031 & 0 & 0.01 & 1.00 & 93.40 \\
\hline $28-00100$ & 0.014 & 0 & 0.023 & 0.015 & 0 & 0.01 & 1.00 & 94.40 \\
\hline $20-01100$ & 0 & 0 & 0.018 & 0.03 & 0 & 0.009 & 0.90 & 95.30 \\
\hline $26-00110$ & 0.008 & 0 & 0 & 0.026 & 0.005 & 0.008 & 0.80 & 96.10 \\
\hline $22-01010$ & 0 & 0.006 & 0 & 0.029 & 0 & 0.007 & 0.70 & 96.80 \\
\hline $27-00101$ & 0.002 & 0 & 0.013 & 0.019 & 0 & 0.007 & 0.70 & 97.50 \\
\hline $31-00001$ & 0 & 0 & 0 & 0.012 & 0.024 & 0.007 & 0.70 & 98.20 \\
\hline $30-00010$ & 0 & 0 & 0 & 0.017 & 0.015 & 0.006 & 0.60 & 98.80 \\
\hline $08-11000$ & 0.017 & 0 & 0 & 0.008 & 0.002 & 0.005 & 0.50 & 99.30 \\
\hline $23-01001$ & 0 & 0 & 0 & 0.022 & 0 & 0.004 & 0.40 & 99.70 \\
\hline
\end{tabular}

Note: The values in the two last columns express the probabilities of the scenarios calculated for each expert and for all experts together. The process performed by the SCIM software gives a median solution through a quadratic minimization program and using the data obtained from the surveys.

Source: compiled by the authors. 


\section{Figure 2. Probabilities of Scenarios} in the Form of a Histogram

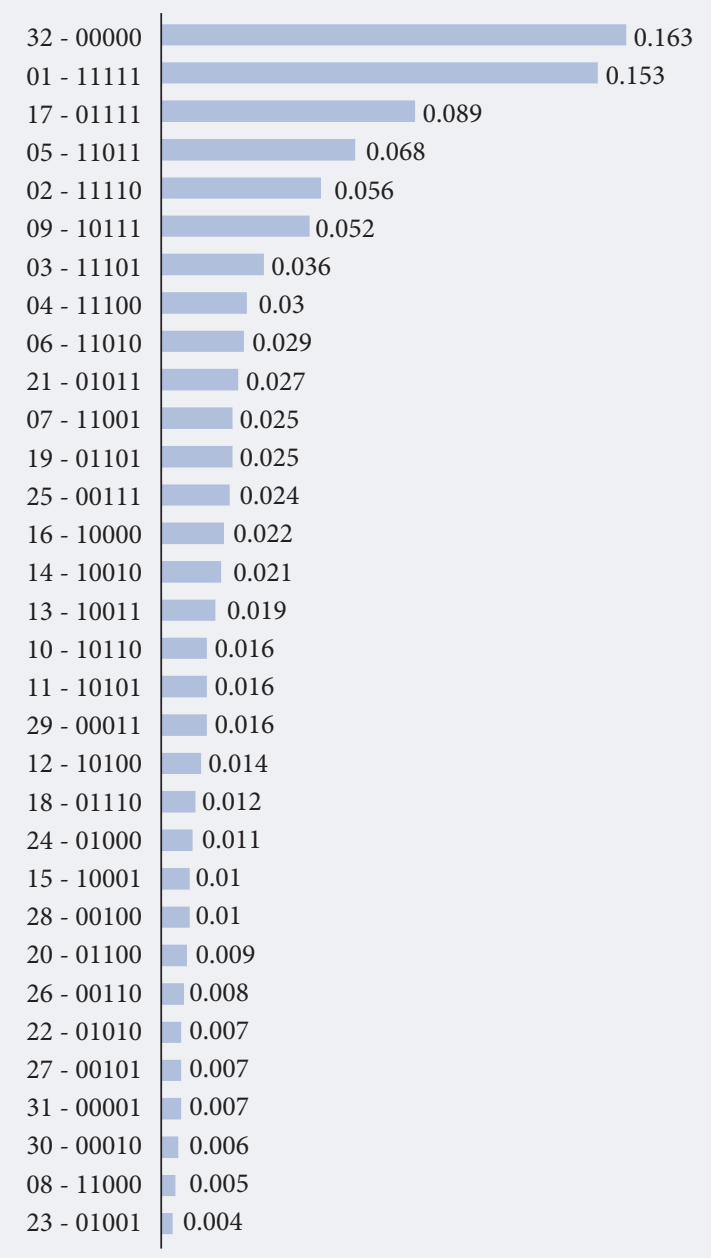

Source: compiled by the authors using SMIC software.

The hypothesis model and its relationships with the best scenario are represented in Figure 3, while Table 11 displays strategic alternatives considering the five hypotheses.

\section{Discussion and Conclusions}

In Ecuador, as in many Latin American countries, MSMEs are the drivers of economic growth and job creation, as well as key contributors to the emerging circular economy model. The views of experts and stakeholders that participated in this study provided important key information about the future of MSMEs that manage waste pneumatic tires in Ecuador. To elaborate upon the possible scenarios for these MSMEs, five hypotheses were constructed. The results of the prospective tools show that scenario 32 - in which no hypotheses are fulfilled - has a $16.3 \%$ probability of occurrence, whereas scenario 01 - in which all five are fulfilled - has a $15.3 \%$ probability. The processing of expert views made it possible to establish recommendations for the most

\section{Figure 3. Hypothesis Model} and Its Relationships - Best Scenario (15.3\%)

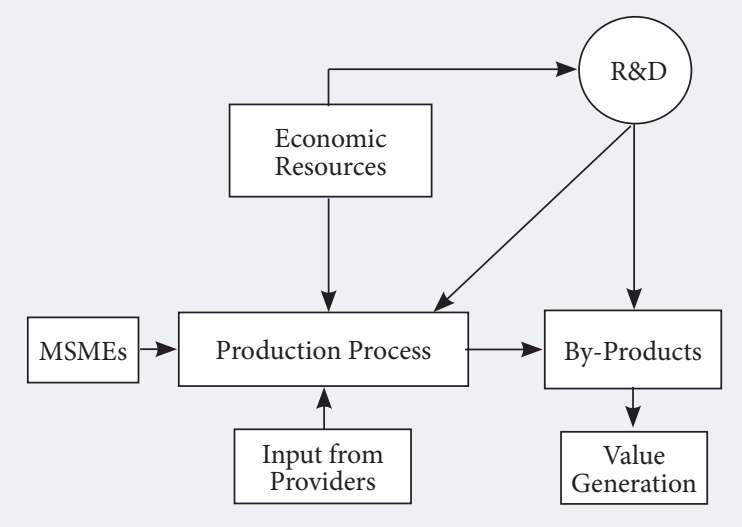

Source:compiled by the authors using [Mojica, 1999].

desirable scenario in which all the hypotheses were fulfilled. These results suggest that for there to be a significant change in these companies, all the variables must be met. That represents a key difference from large companies, where improvements in one area (e.g., finance) may improve the performance of the rest of the areas. Opportunities for the development of MSMEs, as a rule, are limited due to the lack of a qualified management system, the building of which is not considered by the owners of said enterprises as a key resource for development, and therefore they do not seek to master new management and marketing technologies.

As for the MSMEs in waste pneumatic tire management in Ecuador, one of their most relevant weaknesses currently is simply a lack of market consolidation. This is partly due to the fact that plans established in 2013 and 2015 did not consider how to stimulate the last links in the production cycle, namely the market for new products derived from the processing of tire waste. The public, and particularly consumers, do not know enough about needs that can be satisfied by the by-products obtained from waste pneumatic tires. However, marketing capabilities are complex coordinated patterns of skills, knowledge, and activities through which companies transform available resources into market-related value outputs. MSMEs can achieve better organizational performance by developing a market orientation that involves how the MSMEs understand the desires and needs of the market. The challenge of facing the technological advances that affect MSMEs is evident, as well as the effects of the changes in the environment. These are the factors that could threaten the performance of the organizations. To respond them, MSMEs need to develop managerial skills and partnership links that foster knowledge exchange. MSMEs alongside public administration must design strategies to address this challenge. For example: (1) the stimulation of the market through the certification of these products using an ECO seal or 
Table 11. Strategic Alternatives

\begin{tabular}{|c|c|}
\hline Hypotheses & Strategic alternatives \\
\hline $\begin{array}{l}\text { H1: The MSMEs in the sector have a } \\
\text { production process that generates value and } \\
\text { has an environmental policy. }\end{array}$ & $\begin{array}{l}\text { - Generate financial policies that help firms acquire the appropriate technology. } \\
\text { - Strengthen a permanent collaborative link between companies engaged in the } \\
\text { marketing of products made from processed pneumatic waste. }\end{array}$ \\
\hline $\begin{array}{l}\text { H2: The MSMEs of the sector have an efficient } \\
\text { process of input purchases and suppliers that } \\
\text { provide high-quality materials alongside an } \\
\text { environmental policy. }\end{array}$ & $\begin{array}{l}\text { - Create and implement a management capacity development plan for MSMEs of } \\
\text { this sector } \\
\text { - Defined process for identifying suppliers that offer high-quality materials }\end{array}$ \\
\hline $\begin{array}{l}\text { H3: The MSMEs have a system for the } \\
\text { optimization of financial resources }\end{array}$ & $\begin{array}{l}\text { - Define processes to access financing, training, and fiscal incentives with an } \\
\text { established guarantee system. } \\
\text { - Training of existing personnel and hiring of specialists in the handling of economic } \\
\text { and financial issues. } \\
\text { - Establishment of a management style that optimizes financial resources. }\end{array}$ \\
\hline $\begin{array}{l}\text { H4: The MSMEs of the sector will produce } \\
\text { high-quality by-products while protecting the } \\
\text { environment. }\end{array}$ & $\begin{array}{l}\text { - Conduct exhaustive market research to identify existing and potential demand. } \\
\text { - Design marketing strategies in product, price, market, and promotion. } \\
\text { - Incorporation of technology and technical knowledge to increase quality. } \\
\text { - Design strategies that drive sales' growth and profit generation in the sector. }\end{array}$ \\
\hline $\begin{array}{l}\text { H5: The sector's MSMEs have a process that } \\
\text { encourages research and development. }\end{array}$ & $\begin{array}{l}\text { - Involve universities and research centers to find new improvements for production } \\
\text { and management processes of waste pneumatic tires. } \\
\text { - Implement a national fund for Research, Development, and Innovation }(\mathrm{R}+\mathrm{D}+\mathrm{I}) \\
\text { linked to MSMEs that support circular economy practices. }\end{array}$ \\
\hline
\end{tabular}

an environmental certification; (2) positioning of local and international products through labels such as "made in Ecuador"; (3) a linkage to national and international spaces of fair trade; and (4) linkages between large companies and MSMEs (through corporate social responsibility), to promote effective cooperation.

Although the consolidation of the pneumatic waste sector (under a circular economy logic) has the potential to continue growing, prospective studies can only serve as a starting point from which to generate strategies, especially in countries with a high level of economic instability such as Ecuador. Designing and implementing a strategic plan is difficult for MSMEs, however, this study's recommendations are aimed at assisting companies in Ecuador and other countries in this regard. The proposed recommendations should be studied and included in a binding instrument (the next phase of the Plan for the Integrated Management of
Used Tires of the Ministry of Environment of Ecuador, for example, given that this plan expired in 2020) in order for the sector to continue moving forward.

Other points necessary for advancing in the study of MSMEs in the used tire sector is to highlight the potential links of these companies with large private and public companies. It is also important to study how the market for products derived from tire dust or shredded tires could be consolidated

We are grateful for the support of the Dirección General de Investigación y Vinculación (DGIV) de la Universidad de Las Americas (UDLA), Ecuador, who financed the research project "Circular economy in the Ecuadorian context" (ARQ. ADM.19.01) directed by Dr. Angela Díaz-Márquez, that originated this manuscript. Thank you to all the Ecuadorian government entities (Ministry of Environment of Ecuador and City Council), experts, and stakeholders, who answered our questions.

\section{References}

Astigarraga E. (2016) Prospectiva estratégica: Orígenes, conceptos clave e introducción a su práctica, Revista Centroamericana de Administración Pública, (71), 13-29. doi: 10.35485/rcap71_1 (in Spanish).

Bennett N., Lemoine J. (2014) What a Difference a Word Makes: Understanding Threats to Performance in a VUCA World. Business Horizons, 57(3), 311-317. https://doi.org/10.1016/j.bushor.2014.01.001

Berger G. (1964) Phénomenologie du temps et prospective, Paris: Presses Universitaires de France (in French).

Block J. (2012) R\&I investments in family and founder firms: An agency perspective. Journal of Business Venturing, 27(2), 248-265. DOI: 10.1016/j.jbusvent.2010.09.003

Breton-Miller I., Miller D., Lester R.H. (2011) Stewardship or Agency? A Social Embeddedness Reconciliation of Conduct and Performance in Public Family Businesses. Organization Science, 22, pp. 704-721. DOI: 10.1287/orsc.1100.0541.

Burneo S.N. (2016) Inclusión financiera de las pymes en el Ecuador Quito, Quito: Simon Bolivar Andean University. https:// repositorio.cepal.org/bitstream/handle/11362/40726/1/S1601059_es.pdf, accessed 23.02.2021 (in Spanish).

Cassia L., De Massis A., Pizzurno E. (2012) Strategic innovation and new product development in family firms: An empirically grounded theoretical framework. International Journal of Entrepreneurial Behaviour and Research, 18(2), pp. 198-232. DOI: $10.1108 / 13552551211204229$ 
Coates J., Durance P., Godet M. (2010) Strategic Foresight Issue: Introduction. Technological Forecasting and Social Change, 77(9), 1423-1425. DOI: 10.1016/j.techfore.2010.08.001

Cohen S.G., Bailey D.E. (1997) What Makes Teams Work: Group Effectiveness Research from the Shop Floor to the Executive Suite. Journal of Management, 23(3), 239-290. https://doi.org/10.1016/S0149-2063(97)90034-9

Chirico F., Nordqvist M. (2010) Dynamic capabilities and trans-generational value creation in family firms: The role of organizational culture. International Small Business Journal, 28(5), 487-504. https://doi.org/10.1177\%2F0266242610370402

Dabić M., Maley J., Dana L.-P., Novak I., Pellegrini M.M., Caputo A. (2020) Pathways of SME internationalization: A bibliometric and systematic review. Small Business Economics, 55(3), pp. 705-725. https://doi.org/10.1007/s11187-01900181-6

de Jouvenel B. (1967) The Art of Conjecture, New York: Basic Books.

Dekker J., Lybaert N., Steijvers T., Depaire B. (2015) The Effect of Family Business Professionalization as a Multidimensional Construct on Firm Performance. Journal of Small Business Management, 53(2), 516-538. https://doi.org/10.1111/jsbm.12082

Diéguez-Soto J., Garrido-Moreno A., Manzaneque M. (2018) Unravelling the link between process innovation inputs and outputs: The moderating role of family management. Journal of Family Business Strategy, 9(2), 114-127. https://doi. org/10.1016/j.jfbs.2017.11.007

Dobrotă D., Dobrotă G. (2018) An innovative method in the regeneration of waste rubber and the sustainable development. Journal of Cleaner Production, 172, 3591-3599. https://doi.org/10.1016/j.jclepro.2017.03.022

Dobrotă D., Dobrotă G., Dobrescu T. (2020) Improvement of waste tyre recycling technology based on a new tyre markings. Journal of Cleaner Production, 260, 121141 https://doi.org/10.1016/j.jclepro.2020.121141

Doheny M., Nagali V., Weig F. (2012) Agile operations for volatile times. McKinsey Quarterly, May 2012. https://www. mckinsey.com/business-functions/operations/our-insights/agile-operations-for-volatile-times\#, accessed 23.02.2021.

García Peñalvo F.J. (2010) Gestión del Conocimiento y la Tecnología, Salamanca: Universidad de Salamanca. https://repositorio. grial.eu/bitstream/grial/236/1/Gestion_del_conocimiento_y_de_la_tecnologia_GRIAL.pdf, accessed 23.02.2021 (in Spanish).

Gavetti G., Menon A. (2016) Evolution Cum Agency: Toward a Model of Strategic Foresight. Strategy Science, 1(3), $207-233$. https://doi.org/10.1287/stsc.2016.0018

Godet M. (2011) Strategic Foresight for For Corporate and Regional Development, Paris: UNESCO.

Godet M., Durance P. (2011) Strategic Foresight: Use and Misuse of Scenario Building, Paris: UNESCO. http://www.laprospective. $\mathrm{fr} /$ dyn/francais/actualites/SR10vEng.pdf, accessed 23.02.2021.

Gunday G., Ulusoy G., Kilic K., Alpkan L. (2011) Effects of innovation types on firm performance. International Journal of Production Economics, 133(2), 662-676. https://doi.org/10.1016/j.ijpe.2011.05.014

Hambrick D.C., Mason P.A. (1984) Upper Echelons: The Organization as a Reflection of Its Top Managers. The Academy of Management Review, 9(2), 193-206. DOI: 10.2307/258434

Herrmann P., Nadkarni S. (2014) Managing strategic change: The duality of CEO personality. Strategic Management Journal, 35(9), 1318-1342. https://doi.org/10.1002/smj.2156

Howorth C., Wright M., Westhead P., Allcock D. (2016) Company metamorphosis: professionalization waves, family firms and management buyouts. Small Business Economics, 47(3), 803-817. https://doi.org/10.1007/s11187-016-9761-6

Hutajulu S., Dhewanto W., Prasetio E.A. (2020) Two scenarios for 5G deployment in Indonesia. Technological Forecasting and Social Change, 160, 120221. https://doi.org/10.1016/j.techfore.2020.120221

INEC (2019) Directorio De Empresas Ecuador 2018, Quito: Instituto Nacional de Estadística y Censos (in Spanish).

INEC (2020) Clasificación Nacional de Actividades Económicas, Quito: Instituto Nacional de Estadística y Censos (in Spanish).

Kaza S., Yo L., Bhada-Tata P., Van Woerden F. (2018) What a Waste 2.0: A Global Snapshot of Solid Waste Management to 2050, Washington, D.C.: World Bank Group. https://doi.org/10.1596/978-1-4648-1329-0

Laure C., De Lassus C., Moguel A. (2017) Cómo lograr un reciclaje confiable, eficiente y sustentable a través de la economía circular en américa latina, Mexico: Fundación para el Desarrollo Sostenible en América Latina (FUNDES) (in Spanish).

Medina Vásquez J. (2006) Manual de prospectiva y decisión estratégica: Bases teóricas e instrumentos para América Latina y el Caribe, Santiago: Comisión Económica para América Latina y el Caribe (CEPAL). https://repositorio.cepal.org/bitstream/ handle/11362/5490/1/S0600190_es.pdf, accessed 23.02.2021 (in Spanish).

Migliori S., De Massis A., Maturo F., Paolone F. (2020) How does family management affect innovation investment propensity? The key role of innovation impulses. Journal of Business Research, 113, 243-256.

Mitma J.I., Pinzás A.C., Contreras C.C. (2009) Prospectiva estratégica al sector textil del distrito de San Juan de Lurigancho. Industrial Data, 12(2), 40-49. DOI: 10.15381/idata.v12i2.6118 (in Spanish).

Mojica F.J. (1999) Determinism and construction of the future, Bogota: Universidad Externado de Colombia.

OECD (2019) OECD SME and Entrepreneurship Outlook 2019 Policy Highlights. Paris: OECD. DOI: 10.1787/9789264009257en.

Peter M., Jarratt D. (2015) The practice of foresight in long-term planning. Technological Forecasting and Social Change, 101, 49-61. https://doi.org/10.1016/j.techfore.2013.12.004 
Quinteros J., Hamann A. (2017) Planteamiento Estratégico Prospectivo. Métodos MACTOR y SMIC (1st ed.), Bogotá: ECOE Ediciones (in Spanish).

Rohrbeck R. (2012) Exploring value creation from corporate-foresight activities. Futures, 44(5), 440-452. https://doi. org/10.1016/j.futures.2012.03.006

Schwartz P. (1996) The Art of the Long View: Scenario Planning - Protecting Your Company Against an Uncertain Future, New York: Wiley.

Stephenson D., Faucher I. (2019) Estudio comparativo de las legislaciones y políticas públicas de Responsabilidad Extendida del Productor para envases y contenedores, Bogotá: IRR https://latitudr.org/wp-content/uploads/2018/12/Estudio-REP-IRR-1. pdf (in Spanish).

Teece D.J., Pisano G., Shuen A. (2009) Dynamic capabilities and strategic management. Knowledge and Strategy, 18, 77-116. DOI: 10.1142/9789812796929_0004.

Un C.A., Asakawa K. (2015) Types of R\&D Collaborations and Process Innovation: The Benefit of Collaborating Upstream in the Knowledge Chain. Journal of Product Innovation Management, 32(1), https://doi.org/10.1111/jpim.12229

Vandekerkhof P., Steijvers T., Hendriks W., Voordeckers W. (2015) The Effect of Organizational Characteristics on the Appointment of Nonfamily Managers in Private Family Firms: The Moderating Role of Socioemotional Wealth. Family Business Review, 28(2), 104-122. https://doi.org/10.1177\%2F0894486513514274

Vandekerkhof P., Steijvers T., Hendriks W., Voordeckers W. (2018) Socio-Emotional Wealth Separation and Decision-Making Quality in Family Firm TMTs: The Moderating Role of Psychological Safety. Journal of Management Studies, 55(4), 648-676. https://doi.org/10.1111/joms.12277

Volberda H., Foss N.J., Lyles M.A. (2010) PERSPECTIVE - Absorbing the Concept of Absorptive Capacity: How to Realize Its Potential in the Organization Field. Organization Science, 21(4), 931-951. http://www.jstor.org/stable/40792483

Wilden R., Devinney T.M., Dowling G.R. (2016) The Architecture of Dynamic Capability Research Identifying the Building Blocks of a Configurational Approach. Academy of Management Annals, 10(1), 997-1076 . https://doi.org/10.1080/194165 20.2016.1161966

World Bank (2017) Report on the Treatment of MSME Insolvency. Washington, D.C.: World Bank. https://openknowledge. worldbank.org/handle/10986/26709, accessed 23.02.2021.

Zahra S.A., Hayton J.C., Salvato C. (2004) Entrepreneurship in Family vs. Non-Family Firms: A Resource-Based Analysis of the Effect of Organizational Culture. Entrepreneurship Theory and Practice, 28(4), 363-381. https://doi.org/10.1111\%2Fj.15406520.2004.00051.x 